\title{
Founder mutations of CYPIB 1 gene in patients with congenital glaucoma from the United States and Brazil
}

\author{
D F Sena, S Finzi, K Rodgers, E Del Bono, J L Haines, J L Wiggs
}

J Med Genet 2004;41:e6 (http://www.jmedgenet.com/cgi/content/full/41/1/e6)

$\mathrm{P}$ imary congenital glaucoma is an important cause of childhood blindness worldwide. In congenital glaucoma, the anterior segment of the eye fails to develop completely; this results, in particular, in malformation of the trabecular meshwork and aqueous outflow pathways. ${ }^{12}$ Although sporadic cases arise frequently, many cases of congenital glaucoma are inherited as an autosomal recessive trait, and the disease is common, particularly in countries in which consanguinity is customary.

One gene responsible for autosomal recessive congenital glaucoma, CYPIBI, has been discovered. ${ }^{45}$ This gene codes for cytochrome $\mathrm{P} 450 \mathrm{BB1}$, a monooxygenase that may be involved in the metabolism of a variety of substrates, including steroids and retinoids. ${ }^{6}$ Although the role the gene product plays in congenital glaucoma is not well understood, the protein is likely to be responsible for the metabolism of another compound or compounds that perform critical functions in the developing eye. Interestingly, heterozygous carriers of mutations of CYPIBI do not have clinically evident ocular or systemic phenotypic abnormalities. ${ }^{7}$

The CYPIBI gene is composed of three exons, two of which are translated to produce the protein. Mutations that cause congenital glaucoma have been found in exons 2 and 3 . Missense and frameshift mutations have been identified, with most of the missense mutations occurring in highly conserved functional regions of the gene. ${ }^{8}$ Mutations were first found in this gene in a population of Turkish patients with congenital glaucoma. ${ }^{4}$ Subsequently, different mutations have been found in a variety of ethnic groups, including Saudi Arabians, Japanese people, and Slovakian gypsies. ${ }^{5-11}$

Most of the mutations of CYPIBI in patients with congenital glaucoma have been identified in ethnically homogeneous populations. In an earlier study, we screened American and Brazilian families with congenital glaucoma for mutations of the CYPIBI gene to determine the frequency of mutations of CYPIBI in patients with congenital glaucoma in ethnically diverse populations: $3 / 21$ families had mutations of CYPIBI (Finzi S, Figureiredo Sena D, Del Bono E, Haines JL, Wiggs JL. Clinical phenotypes associated with CYPIBl mutations in patients with congenital glaucoma from the U.S. and Brazil. Manuscript submitted). Interestingly, all of the mutations we found had been identified previously in other populations (and two were found in the American and Brazilian patients in this study).

Recurrent mutations have been described in patients with many human diseases, including cystic fibrosis, ${ }^{12}$ breast cancer associated with mutations in $B R C A 2^{13}$ and juvenile glaucoma associated with mutations in TIGR and Myocilin genes. ${ }^{14}$ The recurrence of a particular mutation may be the result of a "hot spot" for a mutation, such as CpG dinucleotides. ${ }^{15}$ Alternatively, the same mutation may be found in unrelated patients because of migration of a founder chromosome that carries the mutation. In such cases, the genetic markers on the mutant chromosome would be the same in all occurrences and can be matched across

\section{Key points}

- Primary congenital glaucoma, an important cause of childhood blindness worldwide, is characterised by abnormal development of the ocular anterior segment, including the trabecular meshwork and aqueous outflow pathways. Mutations of CYPIBI, the gene that codes for cytochrome P450 1B1, are associated with autosomal recessive congenital glaucoma. Most of the mutations of CYPIBI in patients with congenital glaucoma have been identified in ethnically homogeneous populations, with the highest prevalences in the Turkish, Saudi Arabian, and Slovakian populations.

- The aim of this study was to characterise mutations in CYPIB1 in patients with congenital glaucoma from populations with diverse ethnicity.

- 21 pedigrees from the United States and Brazil were screened for mutations in CYPIBI by direct genomic sequencing.

- Four different mutations were found in three pedigrees. All of the mutations had been identified previously in isolated homogeneous populations, and two mutations (Glu387Lys and 8037_8046dupTCATGCCACC were present in both the Brazilian and American study populations. Haplotypes constructed from seven new microsatellite markers that flank the CYP1B 1 gene and five previously described single nucleotide polymorphisms within the gene were used to establish the identity of the chromosome associated with each mutation. A common haplotype was found for Brazilian and American patients with the Glu387Lys and 8037_8046dupTCATGCCACC mutations, which indicated that migration of an original founder chromosome was responsible for their recurrence. The haplotypes identified in the study population were the same as those associated with these mutations in other populations.

- Four founder mutations were identified in this study in two ethnically heterogeneous populations. The identification of founder mutations of CYPIBI in ethnically diverse populations suggests that these older mutations may have a higher carrier frequency in these populations and that genetic testing for the founder mutations may lead to productive genetic counselling for congenital glaucoma.

populations. This study aimed to determine whether multiple occurrences of mutations in CYPIBI are the result of gene regions prone to mutation or the consequence of inheritance of ancient founder chromosomes. 
Table 1 Oligonucleotide primers used to amplify new microsatellite repeats that flank the CYPIB1 gene

\begin{tabular}{lll}
\hline & Primer & \\
\cline { 2 - 3 } Marker & Forward & Reverse \\
\hline M1 & AGGGTGTTCCTTCTGCTCA & AGGACAATCCCAAGTGACTA \\
M2 & GTGCTGCATTTCTATGAAA & CATGATTAGTACATATCTC \\
M3 & TACGCCAAGACAATAGCCCA & AAAGAGCCAGACTCCGTCTC \\
M4 & CTGCTTCCAAAAACTITTGA & TGTGTAAGGATTTGATCACC \\
M6 & ATCTAAGTGTCCATCAACAG & TAACAAGATGCCCTTCAATT \\
M7 & TCTGTAGGAGCACATAGTCC & GGCACAATCTCAGGAGACTC \\
\hline
\end{tabular}

\section{METHODS}

\section{Participants}

Our research programme followed the tenets of the Declaration of Helsinki and was approved by the institutional review board of the Massachusetts Eye and Ear Infirmary. Informed consent was obtained from the participants after we explained the nature and possible consequences of the study.

We identified nine Brazilian families and 12 American families with one or more members with congenital glaucoma from the ethnically heterogeneous populations of the United States and Brazil. Affected individuals had raised intraocular pressures before they were aged three years. Each family had a pedigree structure consistent with autosomal recessive inheritance. All of these families had lived in Brazil or the United States for at least three generations. The stated ancestry was mainly western European. All patients underwent a complete eye examination, including anterior segment evaluation, with slit lamp, fundoscopy, tonography, and gonioscopy. Congenital glaucoma was defined as an increase in intraocular pressure $>21 \mathrm{~mm} \mathrm{Hg}$ in both eyes before the age of three years.

\section{Microsatellite repeat marker haplotype analysis}

We amplified the portions of exons 2 and 3 of the CYPIBI gene that code for translated sequence and flanking splice sites from genomic DNA in family members affected and unaffected by disease and screened for mutations by direct genomic sequencing. We located microsatellite repeat markers in genomic regions that flank the CYPIBI gene by using BLAST (http://www.ncbi.nlm.nih.gov/BLAST) to identify repeat sequences of $\mathrm{C}$ and $\mathrm{A}$ nucleotides in the bacterial artificial chromosomes that contained the CYPIBI genomic sequence (http://ncbi.nlm.nih.gov). We amplified each microsatellite repeat with flanking oligonucleotide primers (table 1). Amplification conditions for all seven new microsatellite repeat markers were $50 \mathrm{ng}$ DNA, 20 pmol of each primer, $200 \mu \mathrm{M}$ nucleotide triphosphate, $50 \mathrm{mM}$ potassium chloride, $20 \mathrm{mM}$ Tris buffer $(\mathrm{pH} \mathrm{8.4),} \mathrm{0.01 \%} \mathrm{Triton} \mathrm{X-}$ 100 (Shun Chia Industrial Company, Taipei, Taiwan), and 0.1 unit Taq DNA polymerase. We incubated samples in an ABI 2700 thermocycler (Applied Biosystems, Foster City, CA, USA) for 5 minutes at $94^{\circ} \mathrm{C}$; for 35 cycles of 45 seconds at $94^{\circ} \mathrm{C}, 45$ seconds at $55^{\circ} \mathrm{C}$, and 45 seconds at $72^{\circ} \mathrm{C}$; and then for 1 minute at $55^{\circ} \mathrm{C}$ and 5 minutes at $72^{\circ} \mathrm{C}$. We separated the amplification products with electrophoresis on $6 \%$ polyacrylamide gel. All the amplification products were 100-300 base pairs long, and alleles were resolved after 2.5 hours of electrophoresis at $80 \mathrm{~W}$ (constant voltage). We stained the gel with SYBR Green Dye (Roche Molecular Pharmaceuticals, Nutley, NJ, USA) and identified alleles with a fluorescent imager (Bio-Rad FX; Bio-Rad Laboratories, Hercules, CA, USA).

\section{DNA sequencing}

We used oligonucleotides that flanked and were within the translated exons of the CYPIBI gene to amplify genomic DNA purified from each affected participant and relevant family members. Primers were based on sequences identified by the primer3 software (http://www-genome.wi. mit.edu/cgi-bin/primer/primer3_www.cgi) and are available on request. Exon 2 was amplified as five overlapping fragments and exon 3 as two overlapping fragments. The amplification products were sequenced with BigDye Chemistry software (Applied Biosystems, Foster City, CA, USA) and an ABI 310 automated sequencer (Global Medical Instrumentation, Albertville, Minnesota, USA). Each fragment was sequenced in the forward and reverse direction.

\section{RESULTS}

A total of 126 people $(51$ affected by disease and 75 unaffected) were screened for mutations. Mutations were

Table 2 CYP1B1 mutations in patients with congenital glaucoma from multiple populations

\begin{tabular}{|c|c|c|c|c|}
\hline Mutation & $\begin{array}{l}\text { Location in } \\
\text { molecule }\end{array}$ & Origin & $\begin{array}{l}\text { Identified } \\
\text { in this } \\
\text { study }\end{array}$ & $\begin{array}{l}\text { Other studies } \\
\text { that identified } \\
\text { mutation }\end{array}$ \\
\hline Trp57Stop & $\begin{array}{l}\text { Exon 2, } \\
\text { hinge region }\end{array}$ & $\begin{array}{l}\text { Brazil } \\
\text { Canada }\end{array}$ & & $\begin{array}{l}16 \\
17\end{array}$ \\
\hline Gly61Glu & $\begin{array}{l}\text { Exon } 2 \text {, } \\
\text { hinge region }\end{array}$ & $\begin{array}{l}\text { Morocco } \\
\text { Turkey } \\
\text { Saudi Arabia } \\
\text { Indian }\end{array}$ & & $\begin{array}{l}18 \\
8 \\
19 \\
20\end{array}$ \\
\hline Arg $368 \mathrm{His}$ & $\begin{array}{l}\text { Exon 3, } \\
\text { J helix }\end{array}$ & $\begin{array}{l}\text { Saudi Arabia } \\
\text { Brazil } \\
\text { Indian }\end{array}$ & & $\begin{array}{l}21 \\
16 \\
20\end{array}$ \\
\hline Glu387Lys & $\begin{array}{l}\text { Exon 3, } \\
\text { K helix }\end{array}$ & $\begin{array}{l}\text { Slovakian } \\
\text { gypsies } \\
\text { Canadian } \\
\text { Brazil } \\
\text { USA }\end{array}$ & Yes & $\begin{array}{l}11 \\
8,21 \\
16 \\
8\end{array}$ \\
\hline Pro437Leu & $\begin{array}{l}\text { Exon 3, } \\
\text { meander }\end{array}$ & $\begin{array}{l}\text { Brazil } \\
\text { Turkey }\end{array}$ & & $\begin{array}{l}16 \\
8\end{array}$ \\
\hline Ala443Gly & $\begin{array}{l}\text { Exon 3, } \\
\text { meander }\end{array}$ & $\begin{array}{l}\text { Germany } \\
\text { Brazil }\end{array}$ & & $\begin{array}{l}22 \\
16\end{array}$ \\
\hline Arg469Trp & $\begin{array}{l}\text { Exon } 3 \text {, } \\
\text { heme binding }\end{array}$ & $\begin{array}{l}\text { Saudi Arabia } \\
\text { British } \\
\text { Turkish }\end{array}$ & & $\begin{array}{l}5 \\
8 \\
8\end{array}$ \\
\hline 268delSNF & Exon 2 & $\begin{array}{l}\text { Saudi Arabia } \\
\text { USA }\end{array}$ & Yes & 19 \\
\hline $\begin{array}{l}4339 / \\
4340 \text { delG }\end{array}$ & Exon 2 & $\begin{array}{l}\text { Brazil } \\
\text { Morocco }\end{array}$ & & $\begin{array}{l}16 \\
18\end{array}$ \\
\hline $\begin{array}{l}8037 \text { 8046- } \\
\text { dupTCATG- } \\
\text { CCACC }\end{array}$ & $\begin{array}{l}\text { Exon 3, } \\
\text { frameshift }\end{array}$ & $\begin{array}{l}\text { Germany } \\
\text { Brazil } \\
\text { USA } \\
\text { British } \\
\text { Turkey }\end{array}$ & Yes & $\begin{array}{l}22,23 \\
16 \\
8 \\
8 \\
8\end{array}$ \\
\hline $8182 \mathrm{delG}$ & $\begin{array}{l}\text { Exon 3, } \\
\text { frameshift }\end{array}$ & $\begin{array}{l}\text { Brazil } \\
\text { USA }\end{array}$ & Yes & $\begin{array}{l}16 \\
8\end{array}$ \\
\hline
\end{tabular}




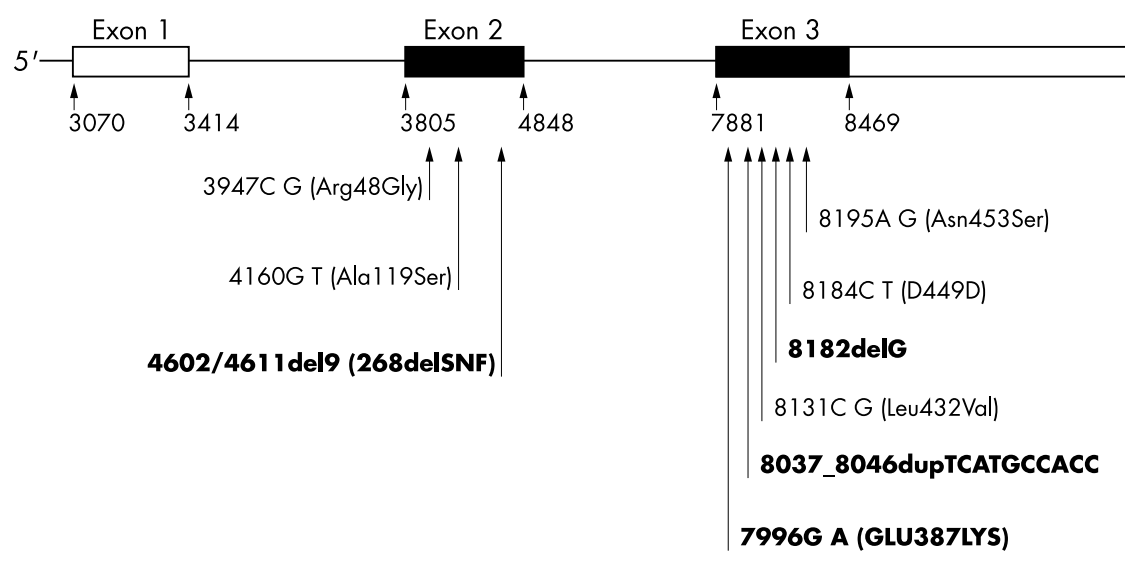

Figure 1 CYPIB 1 gene structure showing location of intron and exon boundaries and mutations identified in study population and single nucleotide polymorphisms used for haplotype analysis. DNA sequence variants associated with disease shown in bold. Nucleotide positions determined according to CYPIB1 Genbank accession number U56438.

A

Pedigree B7 (Brazilian)

।

$\|$

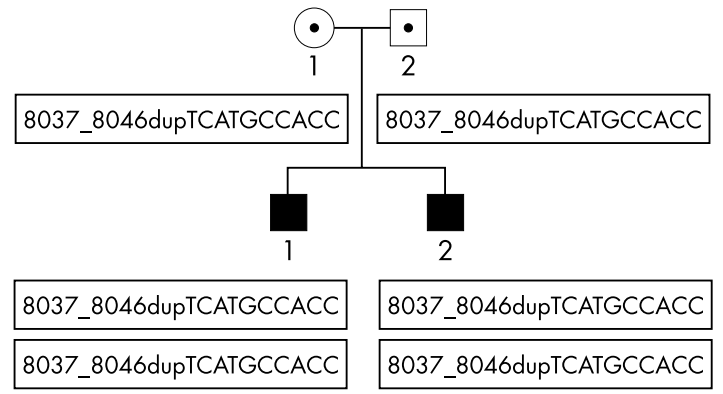

B

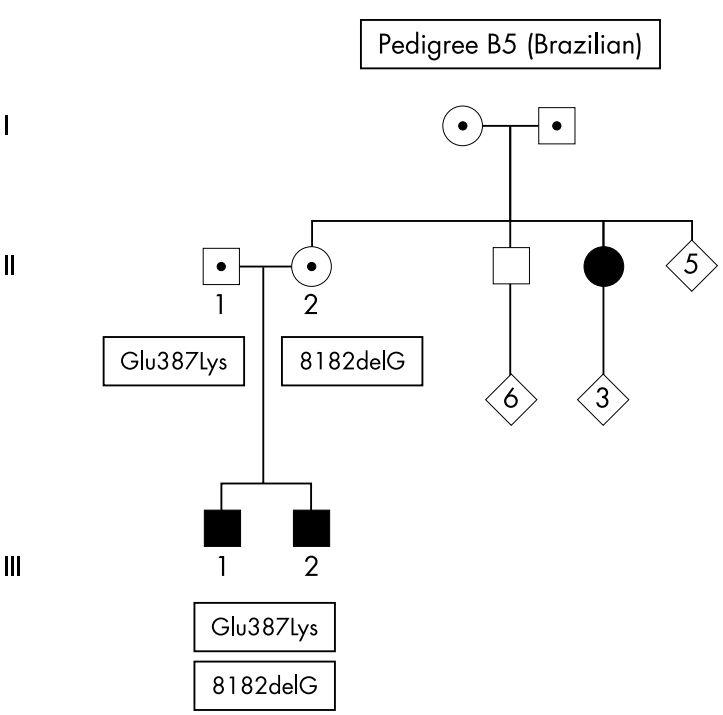

C

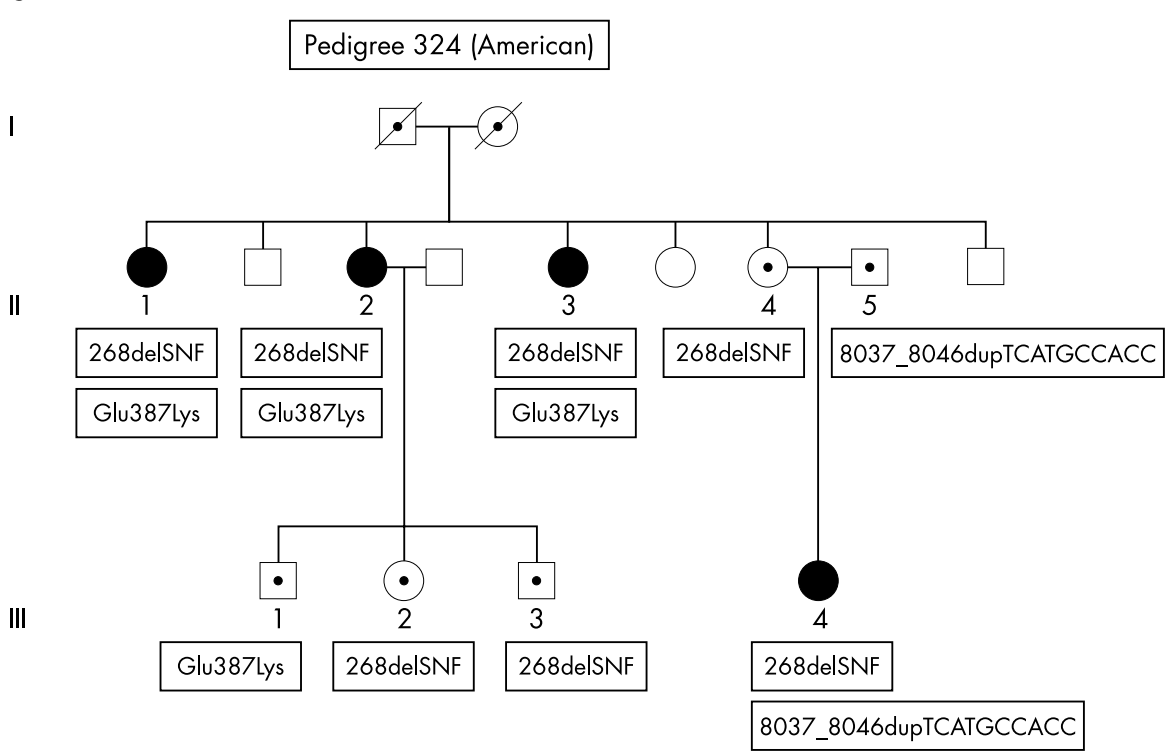

Figure 2 Pedigrees with congenital glaucoma with mutations of CYPIB1. @ $\mathbf{\square}$ affected people; $\odot, \odot$ heterozygous carriers. Mutations carried by family member shown below pedigree symbol. 

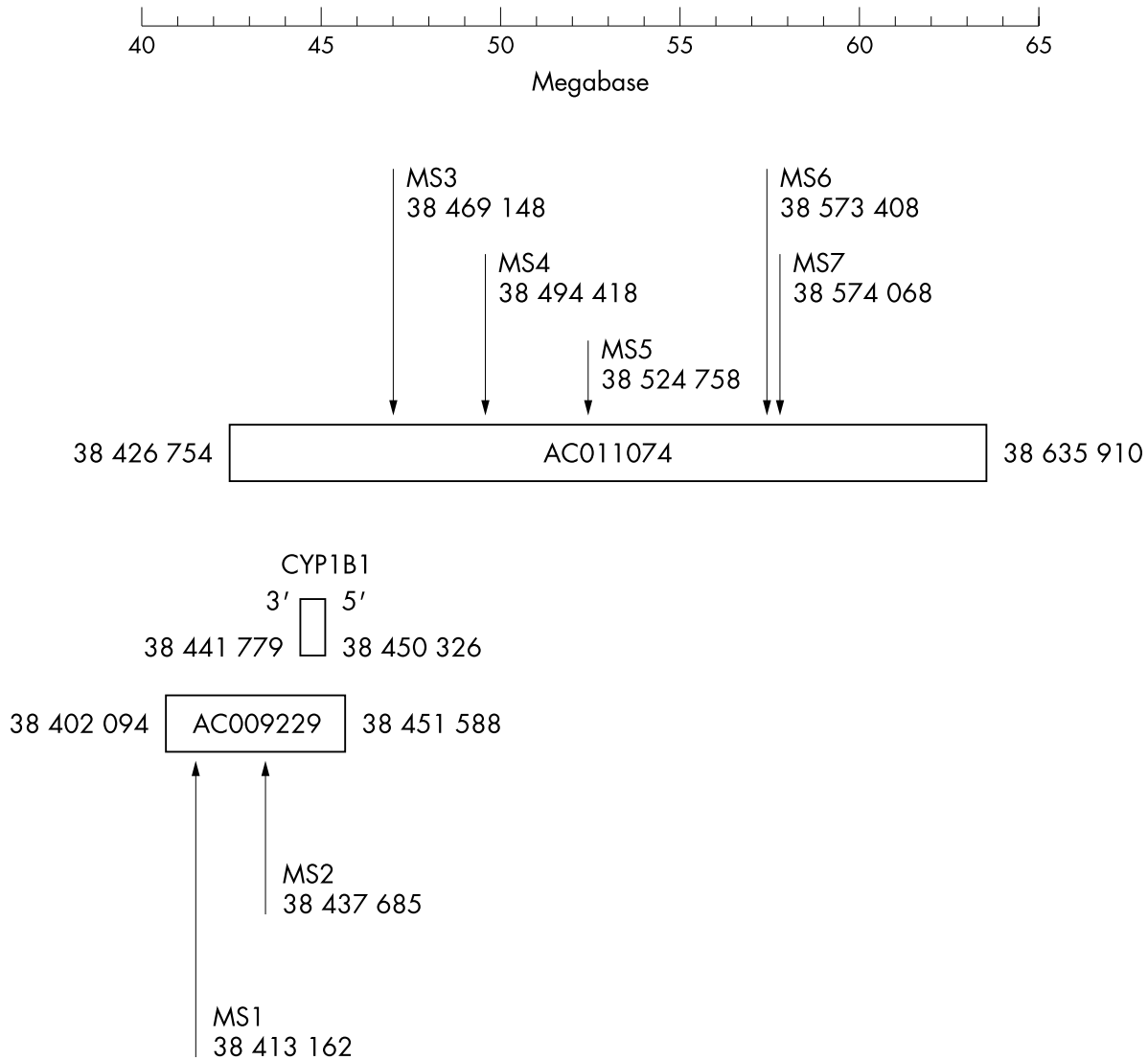

Figure 3 Location of novel microsatellite repeat markers in the genomic sequence (bacterial artificial chromosomes AC011074 and AC009229) that flank CYPIB1 gene. Alignment of bacterial artificial chromosome sequences with CYPIB1 gene and five novel microsatellite markers was done with BLAST (www.ncbi.nih.nlm.gov) and BLAT (www.genome.ucsc.edu).

found in two Brazilian families and one American family (fig 1). People with mutations had raised intraocular pressures before they were aged three years. In each family, the inheritance of the disease was consistent with an autosomal recessive pattern. In affected members from the two Brazilian families, three different mutations were found: 8037 8046dupTCATGCCACC, 8182delG, and Glu387Lys (fig 2A and 2B). The mutation 8037 8046dupTCATGCCACC is a duplication of 10 base pairs that occurs in exon 3 and causes a frameshift that leads to premature termination of the polypeptide chain. The mutation 8182 delG is also a frameshift mutation, while Glu387Lys is a missense mutation that occurs in the highly conserved $\mathrm{K}$ helix of the protein. In family B7, both parents were heterozygous

Table 3 Intragenic haplotypes associated with mutations of CYPIB 1 found in multiple populations

\begin{tabular}{|c|c|c|c|c|c|c|c|c|}
\hline Mutation & Origin & $\begin{array}{l}\text { Arg48Gly } \\
\text { (C/G) }\end{array}$ & $\begin{array}{l}\text { Ala1 19Ser } \\
\text { (G/T) }\end{array}$ & $\begin{array}{l}\text { Val432Leu } \\
\text { (G/C) }\end{array}$ & $\begin{array}{l}\text { Asp449Asp } \\
\text { (T/C) }\end{array}$ & $\begin{array}{l}\text { Asn453Ser } \\
\text { (A/G) }\end{array}$ & $\begin{array}{l}\text { Identified in } \\
\text { this study }\end{array}$ & $\begin{array}{l}\text { Studies that } \\
\text { identified } \\
\text { mutation }\end{array}$ \\
\hline \multirow[t]{2}{*}{ Try57Stop } & Canada & NA & NA & NA & NA & NA & & 17 \\
\hline & Brazil & C & G & $G$ & $\mathrm{~T}$ & A & & 16 \\
\hline \multirow[t]{2}{*}{ Gly61Glu } & Saudi Arabia & C & G & G & T & A & & 19 \\
\hline & Morocco & C & G & G & $\mathrm{T}$ & A & & 18 \\
\hline \multirow[t]{2}{*}{ Arg368His } & Saudi Arabia & C & G & G & $\mathrm{T}$ & A & & 19 \\
\hline & Brazil & C & G & G & T & A & & 16 \\
\hline \multirow[t]{4}{*}{ Glu387Lys } & Romania & G & $\mathrm{T}$ & C & C & A & & 11 \\
\hline & Brazil & G & $\mathrm{T}$ & C & C & A & & 16 \\
\hline & USA & G & $\mathrm{T}$ & C & C & A & Yes & \\
\hline & Brazil & G & T & C & C & A & Yes & \\
\hline \multirow[t]{2}{*}{ 4339/4340delG } & Brazil & C & G & G & T & A & & 16 \\
\hline & Morocco & C & G & G & $\mathrm{T}$ & A & & 18 \\
\hline \multirow{2}{*}{ 268delSNF } & Saudi Arabia & C & G & G & $\mathrm{T}$ & A & & 19 \\
\hline & USA & C & G & G & $\mathrm{T}$ & A & Yes & \\
\hline \multirow{3}{*}{$\begin{array}{l}\text { 8037_8046dup- } \\
\text { TCATGCCACC }\end{array}$} & Brazil & C & G & G & T & A & & 16 \\
\hline & Brazil & C & G & G & $T$ & A & Yes & \\
\hline & USA & C & G & G & T & A & Yes & \\
\hline \multirow[t]{2}{*}{ 8182delG } & Brazil & C & G & C & C & G & & 16 \\
\hline & Brazil & C & G & C & C & G & Yes & \\
\hline
\end{tabular}

NA, not available. 


\begin{tabular}{|c|c|c|c|}
\hline Marker & $\begin{array}{l}\text { Number } \\
\text { of alleles }\end{array}$ & Allele & Frequency \\
\hline \multirow[t]{9}{*}{ Ml } & 9 & 267 & 0.10 \\
\hline & & 265 & 0.15 \\
\hline & & 263 & 0.25 \\
\hline & & 261 & 0.10 \\
\hline & & 259 & 0.10 \\
\hline & & 257 & 0.15 \\
\hline & & 255 & 0.10 \\
\hline & & 251 & 0.05 \\
\hline & & 247 & 0.05 \\
\hline \multirow[t]{3}{*}{ M2 } & 3 & 159 & 0.60 \\
\hline & & 157 & 0.20 \\
\hline & & 155 & 0.20 \\
\hline \multirow[t]{6}{*}{ M3 } & 6 & 158 & 0.20 \\
\hline & & 154 & 0.15 \\
\hline & & 146 & 0.20 \\
\hline & & 138 & 0.10 \\
\hline & & 134 & 0.20 \\
\hline & & 130 & 0.15 \\
\hline \multirow[t]{6}{*}{ M4 } & 6 & 207 & 0.10 \\
\hline & & 205 & 0.15 \\
\hline & & 203 & 0.20 \\
\hline & & 201 & 0.20 \\
\hline & & 197 & 0.20 \\
\hline & & 195 & 0.15 \\
\hline \multirow[t]{7}{*}{ M5 } & 7 & 170 & 0.10 \\
\hline & & 168 & 0.10 \\
\hline & & 166 & 0.10 \\
\hline & & 164 & 0.20 \\
\hline & & 162 & 0.20 \\
\hline & & 160 & 0.15 \\
\hline & & 150 & 0.15 \\
\hline \multirow[t]{5}{*}{ M6 } & 5 & 113 & 0.15 \\
\hline & & 111 & 0.25 \\
\hline & & 109 & 0.20 \\
\hline & & 107 & 0.20 \\
\hline & & 105 & 0.20 \\
\hline \multirow[t]{4}{*}{ M7 } & 4 & 185 & 0.20 \\
\hline & & 183 & 0.30 \\
\hline & & 181 & 0.30 \\
\hline & & 179 & 0.20 \\
\hline
\end{tabular}

carriers of the 80378046dupTCATGCCACC mutation, and both affected children were homozygous for the mutation. Member II-l was born with corneal oedema and had high intraocular pressure at age one month (early clinical details for II-2 are not available, but examination at age two years showed evidence of surgery for glaucoma, which indicated the disease was present at an early age). In Brazilian family B5, the affected members in generation III were compound heterozygotes with 8182delG and Glu387Lys mutations. Both children had severe early onset glaucoma, with high intraocular pressures and corneal oedema. Their mother's sister also had a history of congenital glaucoma, but clinical details and DNA could not be obtained.

In one American pedigree, three mutations were found: 8037_8046dupTCATGCCACC, Glu387Lys, and 268delSNF
(Fig. 2C). Mutation 268delSNF is a deletion of nine base pairs at position 4602/461l (reference sequence Genbank U56438). The nine base pairs are part of a direct repeat that begins at nucleotide 4602 and ends at 4619 , so it is not possible to distinguish which repeat has been deleted. The nine base pair deletion results in an inframe deletion of three amino acids (serine, asparagine, and phenylalanine (SNF)) that begins at position 268. In the American family, all affected patients in generation II were Glu387Lys and 268delSNF compound heterozygotes. Interestingly, two of the four affected siblings in generation II had severe early onset glaucoma (intraocular pressures of 25 (at age two months) and 28 (at age one month), with associated corneal oedema), but the other two siblings (with the same CYPIBI sequence variants) did not have evidence of glaucoma until their mid teenage years. The affected patient in generation III was also a compound heterozygote but had the 8037_8046dupTCATGCCACC and 268delSNF mutations. This patient was born with severe glaucoma characterised by corneal oedema and high intraocular pressures of 28 OD and 30 OS.

All of the mutations we identified had been found previously in patients from populations with homogeneous ethnicity. Table 2 lists the mutations of CYPIBI we identified in this study as well as mutations in CYPIBI identified in more than one population in other studies.

Two of the mutations identified in this patient population, 8037_8046dupTCATGCCACC and Glu387Lys, were found in a Brazilian pedigree and the American pedigree. These mutations could have originated from a single ancestral mutation or from two independent mutation events. To determine if these mutations resulted from migration of an ancestral chromosome, we constructed haplotypes with alleles from single nucleotide polymorphisms within the CYPIBI gene, as well as novel microsatellite repeat markers in close proximity to the CYPIBl gene. To be certain that the microsatellite repeat markers were located adjacent to the coding regions of the $C Y P I B I$ gene, we identified the bacterial artificial chromosomes from the human genome that contained the CYPIB1 genomic sequences with the publicly available human genome sequence (http://www.genome.ucsc.edu). New microsatellite repeats within the bacterial artificial chromosome sequences that flanked the CYPIBI gene were identified with BLAST (http://www.ncbi.nln.nih.gov). Figure 3 shows the locations of the new microsatellite repeat markers relative to the CYPIBI coding sequence and the sequence position in the bacterial artificial chromosome.

Five single nucleotide polymorphisms previously described within the coding sequence of the CYPIBI gene were informative in our families. ${ }^{4819}$ Population studies indicate that these alleles exist in multiple haplotypes in unaffected populations. ${ }^{16}$ Alleles at each of the single nucleotide polymorphisms were identified by direct genomic sequencing, and haplotypes were determined from segregation of the alleles and the mutations in the affected pedigree. When possible, the intragenic haplotype associated with each

Table 5 Extragenic haplotypes associated with mutations of CYP1B1 in American and Brazilian patients

\begin{tabular}{|c|c|c|c|c|c|c|c|c|}
\hline Pedigree & Mutation & MS1 & MS2 & MS3 & MS4 & MS5 & MS6 & MS7 \\
\hline 324 & 8037_8046dupTCATGCCACC & 259 & 159 & 154 & 203 & 168 & 111 & 181 \\
\hline B7 & 8037_8046dupTCATGCCACC & 259 & 159 & 154 & 203 & 168 & 111 & 183 \\
\hline 324 & Glu387Lys & 267 & 159 & 130 & 203 & 150 & 111 & 183 \\
\hline B5 & Glu387Lys & 267 & 159 & 130 & ND & 150 & 111 & 183 \\
\hline B5 & $8182 \mathrm{delG}$ & 267 & 159 & 134 & ND & 164 & 111 & 183 \\
\hline 324 & 268delSNF & 259 & 159 & 154 & 205 & 162 & 109 & 183 \\
\hline
\end{tabular}


mutation was compared with haplotypes previously published for the same mutation in other populations (table 3).

The affected participants from pedigrees 324 (American) and B7 (Brazilian) that had the 8037_8046dupTCATGCCACC mutation had a common intragenic haplotype, which suggests that they shared a common ancestral chromosome. Similarly, a common haplotype was found in the affected people and in unaffected heterozygous carriers of the American and Brazilian pedigrees with the Glu387Lys mutation. The haplotype of the chromosome with the 8182delG in Brazilian family B5 is likely to be the same as that reported for the same mutation in another Brazilian family. ${ }^{16}$ The haplotype of the chromosome with the SNF268del mutation is also the same as that previously reported for a Saudi Arabian family with this mutation. ${ }^{19}$ The intragenic single nucleotide polymorphism haplotype associated with 268SNFdel is the same as that associated with 8037 8046dupTCATGCCACC.

To further define the haplotypes of the chromosomes with mutations of CYP1B1, we identified alleles at new microsatellite repeat markers that flanked the gene in all members of pedigrees 324, B5, and B7. Two novel microsatellite repeat markers were identified in genomic sequence $3^{\prime}$ to the CYPIBI gene ( $\mathrm{Ml}$ and $\mathrm{M} 2$ ) and five novel microsatellite repeat markers in genomic sequence $5^{\prime}$ to the CYPIBI gene (M3, M4, M5, M6, and M7). These microsatellite repeat markers spanned a 25 megabase region of genomic DNA. Figure 3 shows the position of each microsatellite on the public human genome sequence (http://www.genome.ucsc. edu). Each microsatellite repeat marker had at least three alleles in a control population of 40 American chromosomes. Table 4 shows the alleles and allele frequencies.

The extragenic haplotypes were identified by observing the segregation of microsatellite repeat marker alleles with each mutation in the three pedigrees with mutations of CYPIBI. Table 5 shows that the extragenic haplotype associated with the 8037_8046dupTCATGCCACC mutation in families 324 and B7 was the same. Similarly, the extragenic haplotype associated with the Glu387Lys mutation in families 324 and B5 was the same but was different from that associated with the 8037 8046dupTCATGCCACC mutation. The 268SNFdel intragenic haplotype was the same as that for the 8037 8046dupTCATGCCACC mutation. The extragenic haplotype for these two mutations differed, however, in the genomic region that flanked the 5' end of the gene (M4, M5, M6, and M7). The 8182delG mutation seemed to have intragenic and extragenic haplotypes distinct from any of the other mutations in this study.

\section{DISCUSSION}

Mutations of CYPIBI have been found in patients with congenital glaucoma from defined populations worldwide. In our study, mutations in these genes were also found in populations with diverse ethnicity, although with lower prevalence (3/21 families) than in the ethnically homogenous populations of Turkey and Saudi Arabia. ${ }^{45}$

We identified two frameshift mutations (one deletion and one duplication) that result in premature termination of the polypeptide change and an inactive protein product. We also identified one inframe deletion of nine base pairs and three amino acids, which presumably also causes a loss of function. One missense mutation, Glu387Lys, was identified in this population, which could lead to an inactive protein or a protein with a gain of function or dominant negative effect. The Glu387Lys change occurs in a highly conserved region of the protein, which suggests that the change in amino acid could result in inactivation of protein activity. Interestingly, this mutation is found on a chromosome with a collection of polymorphic variants that independently have been shown to reduce the enzymatic activity of the protein. ${ }^{24}$ The combined effect of the Glu387Lys missense change and the amino acid substitutions Arg48Gly, Ala 1 19Ser, and Leu432Val may result in a significant loss of protein function.

All of the mutations we identified were first described in other populations, ${ }^{5} 8^{1116-23}$ and two of the mutations that we identified in this study we had found in an earlier study of the two populations (Finzi S, Figureiredo Sena D, Del Bono E, Haines JL, Wiggs JL. Clinical phenotypes associated with CYPIBl mutations in patients with congenital glaucoma from the U.S. and Brazil. Manuscript submitted). A number of mutations of CYPIBI have been found in patients from multiple populations (table 2 ). Only the mutations reported in the Japanese population have not been found in any other population. ${ }^{9} 10$

In control populations, the five intragenic single nucleotide polymorphisms used in this study are informative and present in a relatively equal distribution of haplotypes. ${ }^{16} 19$ We showed that newly identified microsatellite repeat markers that flank the CYPIBI gene also are highly informative in control patients from the United States. The probability of inheriting the same five single nucleotide polymorphism alleles in combination with the same seven microsatellite alleles is highly unlikely by chance alone $(\mathrm{p}<0.0001$, assuming linkage equilibrium between microsatellite markers). The identification of the same collection of alleles for these 12 polymorphisms segregating with the same mutation in unrelated patients indicates these people have acquired copies of the same ancestral chromosomes.

Haplotype analysis allowed us to show that 8037_8046dupTCATGCCACC is found on the same ancestral chromosome in the American and Brazilian families in this study. Moreover, this is likely to be the same haplotype associated with this mutation in other Brazilian and American patients. ${ }^{816}$ The 8037_8046dupTCATGCCACC mutation has been found in a number of different ethnic groups (tables 2 and 3) and, although haplotypes have not been published for all of the chromosomes that carry this mutation, a common founder chromosome is likely to be responsible for the multiple occurrences of this mutation in the various populations in which it has been identified. The geographic distribution of 8037_8046dupTCATGCCACC suggests that the founder chromosome has spread widely.

Similarly, the common haplotype of the chromosome that carries the Glu387Lys missense mutation identified in the American and Brazilian families is likely to be the same haplotype as that described for this mutation in patients with congenital glaucoma from Romania and Brazil. ${ }^{11}{ }^{16}$ These results also suggest that this is an ancient chromosome that has migrated to a number of different populations.

The discovery of the 1143/1152del9(SNFdel268) mutation in our American pedigree is the second report of this mutation, which was previously identified in Saudi Arabians. In our study, this is the only mutation associated with variable expression of the disease phenotype. In the Saudi Arabian population, this mutation may also have been associated with a variable phenotype. ${ }^{19}$ The intragenic haplotype of the chromosome that carried this mutation in our American pedigree is the same as that reported for the Saudi Arabian pedigree. ${ }^{19}$ Interestingly, the information from the intragenic single nucleotide polymorphisms suggests that the haplotype of the chromosome that carries the SNFdel268 mutation is the same as the haplotype of the chromosome that carries the 8037_8046dupTCATGCCACC mutation. The extragenic microsatellite repeat alleles are partially the same, which suggests that the chromosomes that carry these two mutations may have had a common origin. The SNFdel268 and 8037 8046dupTCATGCCACC mutations might have arisen independently on the same ancestral chromosome, 
which raises the possibility that the intragenic single nucleotide polymorphism haplotype $(\mathrm{C} / \mathrm{G} / \mathrm{G} / \mathrm{T} / \mathrm{A})$ is prone to mutation.

The 165ldelG mutation was found in one Brazilian pedigree and has been previously reported in another Brazilian pedigree and an American family of Hispanic origin. ${ }^{8}{ }^{16}$ The haplotype associated with this mutation seems to be the same haplotype associated with the previously reported mutation, which suggests that these two Brazilian families carry a common chromosome. A haplotype for the American family was not reported.

We identified four founder mutations in two ethnically diverse populations. Founder mutations are also the oldest mutations, so they may be the most frequent mutations found in an ethnically heterogeneous population. In this study, the married in mutation carriers had the Glu387Lys mutation or the 8037_8046dupTCATGCCACC mutation, which suggests a higher prevalence of these mutations in the general population. It would be interesting to determine the carrier frequency of the founder mutations in the normal American and Brazilian populations. The identification of a panel of mutations of CYPIBI with higher carrier frequency could provide a basis for genetic testing for CYPIBI carrier status and may lead to productive genetic counselling for congenital glaucoma.

\section{ACKNOWLEDGEMENTS}

We thank the families for their willing participation and acknowledge support from the National Eye Institute (ROl EY09847).

\section{Authors' affiliations}

D F Sena, S Finzi, K Rodgers, E Del Bono, J L Wiggs, Department of Ophthalmology, Harvard Medical School, Massachusetts Eye and Ear Infirmary, Boston, Massachusetts 02114, USA

S Finzi, Johns Hopkins Center for Hereditary Eye Diseases, Wilmer Eye Institute, Johns Hopkins Medical School, 600 North Wolfe Street, Maumenee Building Room 846, Baltimore, Maryland 21205, USA J L Haines, Program in Human Genetics, Vanderbilt University School of Medicine, Nashville, Tennessee, USA

Conflicts of interest: None declared.

Correspondence to: Dr J L Wiggs, Assistant Professor of Ophthalmology, Harvard Medical School, Massachusetts Eye and Ear Infirmary, 243 Charles Street, Boston, Massachusetts 02114 , USA; janey_wiggs@meei.harvard.edu

Received 26 May 2003

Accepted 16 June 2003

\section{REFERENCES}

1 Bakunowicz-Lazarczyk A, Sulkowska M, Sulkowski S, Urban B. Ultrastructural changes in the trabecular meshwork of congenital glaucoma. J Submicrosc Cytol Pathol 2001;33:17-22.

2 Deluise VP, Anderson DR. Primary infantile glaucoma (congenital glaucoma). Surv Ophthal 1983;28:1-19.

3 Gencik A, Gencikova A, Ferak V. Population genetical aspects of primary congenital glaucoma. I. Incidence, prevalence, gene frequency, and age of onset. Hum Genet 1982;61:193-7.

4 Stoilov I, Akarsu AN, Sarfarazi M. Identification of three different truncating mutations in cytochrome P4501B1 (CYP1B1) as the principal cause of primary congenital glaucoma (Buphthalmos) in families linked to the GLC3A locus on chromosome 2p21. Hum Mol Genet 1997;6:641-7.

5 Beijani BA, Lewis RA, Tomey KF, Anderson KL, Dueker DK, Jabak M, Astle WF, Otterud B, Leppert M, Lupski JR. Mutations in CYP1B1, the gene for cytochrome $\mathrm{P} 450 \mathrm{~B} 1$, are the predominant cause of primary congenital glaucoma in Saudi Arabia. Am J Hum Genet 1998;62:325-33.

6 Stoilov I, Jansson I, Sarfarazi M, Schenkman JB. Roles of cytochrome p450 in development. Drug Metabol Drug Interact 2001;18:33-55.

7 Garcia-Closas M, Herbstman J, Schiffman M, Glass A, Dorgan JF. Relationship between serum hormone concentrations, reproductive history, alcohol consumption and genetic polymorphisms in pre-menopausal women. Int J Cancer 2002; 102:172-8.

8 Stoilov I, Akarsu AN, Alozie I, Child A, Barsoum-Homsy M, Turacli ME, Or M, Lewis RA, Ozdemir N, Brice G, Aktan SG, Chevrette L, Coca-Prados M, Sarfarazi $M$. Sequence analysis and homology modeling suggest that primary congenital glaucoma on $2 \mathrm{p} 21$ results from mutations disrupting either the hinge region or the conserved core structures of cytochrome P4501B1. Am J Hum Genet 1998;62:573-84.

9 Mashima Y, Suzuki Y, Sergeev Y, Ohtake Y, Tanino T, Kimura I, Miyata H, Aihara $M$, Tanihara $H$, Inatani M, Azuma N, Iwata T, Araie M. Novel cytochrome P4501B1 (CYP1B1) gene mutations in Japanese patients with primary congenital glaucoma. Invest Ophthal Vis Sci 2001 ;42:2211-6.

10 Kakiuchi-Matsumoto T, Isashiki Y, Ohba N, Kimura K, Sonoda S, Unoki K. Cytochrome P450 1B1 gene mutations in Japanese patients with primary congenital glaucoma. Am J Ophthal 2001;131:345-50.

11 Plasilova M, Stoilov I, Sarfarazi M, Kadasi L, Ferakova E, Ferak V. Identification of a single ancestral CYP1B1 mutation in Slovak gypsies (Roms) affected with primary congenital glaucoma. J Med Genet 1999;36:290-4.

12 Morral N, Llevadot R, Casals T, Gasparini P, Macek M Jr, Dork T, Estivill X. Independent origins of cystic fibrosis mutations R334W, R347P, R1 162X, and $3849+10 \mathrm{kbC}-->$ T provide evidence of mutation recurrence in the CFTR gene. Am J Hum Genet 1995;55:890-8.

13 Neuhausen SL, Godwin AK, Gershoni-Baruch R, Schubert E, Garber J, Stoppa-Lyonnet D, Olah E, Csokay B, Serova O, Lalloo F, Osorio A, Stratton M, Offit K, Boyd J, Caligo MA, Scott RJ, Schofield A, Teugels E, Schwab M, Cannon-Albright L, Bishop T, Easton D, Benitez J, King MC, Goldgar D. Haplotype and phenotype analysis of nine recurrent BRCA2 mutations in 111 families: results of an international study. Am J Hum Genet 1998;62:1381-8.

14 Baird PN, Craig JE, Richardson AJ, Ring MA, Sim P, Stanwix S, Foote SJ, Mackey DA. Analysis of 15 primary open-angle glaucoma families from Australia identifies a founder effect for the Q368STOP mutation of myocilin. Hum Genet 2003;112:110-6.

15 Cooper DN, Krawczak M. Cytosine methylation and the fate of CpG dinucleotides in vertebrate genomes. Hum Genet 1989;83:181-8.

16 Stoilov IR, Costa VP, Vasconcellos JPC, Melo MB, Betinijane AJ, Carani JCE, Oltrogge EV, Sarfarazi M. Molecular genetics of primary congenital glaucoma in Brazil. Invest Opthal Vis Sci 2003;43:1820-7.

17 Vincent A, Billingsley G, Priston M, Williams-Lyn D, Sutherland J, Glaser T, Oliver E, Walter MA, Heathcote G, Levin A, Heon E. Phenotypic heterogeneity of CYP1B1: mutations in a patient with Peters' anomaly. J Med Genet 2001;38:324-6.

18 Belmouden A, Melki R, Hamdani M, Zaghloul K, Amraoui A, Nadifi S, Akhayat $\mathrm{O}$, Garchon $\mathrm{H}-\mathrm{J}$. A novel frameshift founder mutation in the cytochrome P450 1B1 (CYP1B1) gene is associated with primary congenital glaucoma in Morocco. Clin Genet 2002;62:334-9.

19 Beijani BA, Stockton DW, Lewis RA, Tomey KF, Dueker DK, Jabak M, Astle WF, Lupski JR. Multiple CYP1B1 mutations and incomplete penetrance in an inbred population segregating primary congenital glaucoma suggest frequent de novo events and a dominant modifier locus. Hum Mol Genet 2000;9:367-74.

20 Panicker SG, Reddy AB, Mandal AK, Ahmed N, Nagarajaram HA, Hasnain SE, Balasubramanian D. Identification of novel mutations causing familial primary congenital glaucoma in Indian pedigrees. Invest Ophthal Vis Sci 2002;43:1358-66

21 Martin SN, Sutherland J, Levin AV, Klose R, Priston M, Heon E. Molecular characterization of congenital glaucoma in a consanguineous Canadian community: a step towards preventing glaucoma related blindness. J Med Genet 2000;37:422-7.

22 Michels-Rautenstrauss KG, Mardin CY, Zenker M, Jordan N, GusekSchneider G-C, Rautenstrauss BW. Primary congenital glaucoma: three case reports on novel mutations and combinations of mutations in the GLC3A (CYP1B1) Gene. J Glaucoma 2001;10:354-7.

23 Soley GC, Bosse KA, Flikier D, Flikier P, Azofeifa J, Mardin CY, Reis A, Michels-Rautenstrauss KG, Rautenstrauss BW. Primary congenital glaucoma: a novel single-nucleotide deletion and varying phenotypic expression for the 1546-1555dup mutation in the GLC3A (CYP1B1) gene in 2 families of different ethnic origin. J Glaucoma 2003;12:27-30.

24 Aklillu E, Oscarson M, Hidestrand M, Leidvik B, Otter C, IngelmanSundberg M. Functional analysis of six different polymorphic CYP1B1 enzyme variants found in an Ethiopian population. Mol Pharmacol 2002;61:586-94. 